McQuaid R \& Grieco M (2005) Edinburgh and the politics of congestion charging: Negotiating road user charging with affected publics, Transport Policy, 12 (5), pp. 475476.

This is the peer reviewed version of this article

NOTICE: this is the author's version of a work that was accepted for publication in Transport Policy. Changes resulting from the publishing process, such as peer review, editing, corrections, structural formatting, and other quality control mechanisms may not be reflected in this document. Changes may have been made to this work since it was submitted for publication. A definitive version was subsequently published in Transport Policy, [VOL 12, ISS 5 (2005)] DOI:

http://dx.doi.org/10.1016/j.tranpol.2005.06.005 


\title{
Edinburgh and the politics of congestion charging: negotiating road user charging with affected publics.
}

\author{
Ronald McQuaid, Napier University and Margaret Grieco, Napier University, \\ Edinburgh and Cornell University. Contact: r.mcquaid@ napier.ac.uk or \\ mg294@cornell.edu
}

Prepublication copy of: McQuaid, R.W. and M. Grieco (2005) 'Edinburgh and the politics of congestion charging: negotiating road user charging with affected publics', Transport Policy, 12, 475-476.

\begin{abstract}
The citizens of Edinburgh have just rejected a congestion charging scheme for this capital city. This short postscript examines the case for a full post-mortem, a post-mortem which must include the participation of those who said no.
\end{abstract}

In the slipstream of the introduction of congestion charging in London, the case for road user charging in Edinburgh was vigorously made by a set of policy agencies, transportation experts and green advocacy groups. The public were consulted in this process but the outcome of a vote on road user charging demonstrates they were not persuaded ( http://news.bbc.co.uk/1/hi/scotland/4287145.stm). They voted against road user charging 3:1. The post-mortem is now taking place: what caused the "no"? was it the particularities of this scheme which contained acknowledged inequities? or was there a failure to fully educate the public on the workings and benefits of road user charging? The city council after having invested considerable energy on this transport policy now state they respect the wishes of the citizens, the policy is now dead and they wish to move on with other measures. The green advocacy groups charge the local press with an unfair hearing and a concerted campaign against the policy. The transport specialists are left with an outcome which, in all probability, moves the general acceptability of road user charging backwards in Britain. There is considerable repair work to do on road user charging. Developing schemes which pay attention to the local specificities of urban functioning and which address directly equity issues becomes the key: correspondingly, the sharing of technical knowledge with the public becomes an imperative if the vote of the public is required in the introduction of road user charging measures. 
Most studies of road pricing identify the motivations of reducing congestion and revenue generation, for improving public transport or other reason, and focus on economics, social and technological feasibility (see Button and Vefhoef 1998 and Han 1998) at the expense of the explicit discussion of the political. However, Grieco and Jones (1994) and Fietelson and Solomon (2004) argue that the adoption of transport innovations is the outcome of a political process rather than just the diffusion of technical and/or policy innovation. The level, range and intensity of opposition to road user charging will determine the likelihood of its adoption. The current rejection of road user charging by the citizens of Edinburgh in March 2005, as well as the vigorous opposition to this proposal by adjacent local authorities and their citizens (Rajé, Grieco and McQuaid, 2004), demonstrates the importance of understanding and correctly gauging the local political dimensions in building any policy platform for the introduction of road user charging.

There is a literature on the regressive income distribution effects which needs to be considered (see for instance, Layard 1977) although it is also important to consider redistribution effects between user and non users (Rietveld and Verhoef 1988; Small and Gomez - Ibanez, 1998). In addition, low income and part-time workers who need to cross the cordon may be particularly affected by tolls as their travel distances are shorter and tolls would be higher relative to their incomes (see McQuaid et al. 2001). The winners from new policies are likely to be less strident than economic losers. Partly as a result Feitelson and Solomon (2004) suggest that bureaucracies and local politicians have little incentive to move to road user charging as they will face opposition from interest groups, users negatively affected (potential losers) but get little support from non-user or user beneficiaries (winners) (see for instance, Jones 1991; Harrington et al. 2001). The long term political feasibility appears to have been an important consideration in the design of the Edinburgh proposals. Hence the Edinburgh case is interesting in that local voters were given a referendum.

In assessing the political acceptability of congestion pricing Giliano (1992) argues that the main reason for non-introduction of road pricing are public scepticism about outcomes (i.e. the effectiveness of the schemes), concerns on impact of business and resistance to charges for what is free (i.e. conflicts with prior experience). All of these appear to have been significant in the Edinburgh case (Rajé, Grieco and Mcquaid, 
2004). In addition, Jones (1998) argues that suggests road charging will be seen as another form of tax and that people will be concerned with possible privacy issues.

Levinson (2000) suggests that road charging initiatives are more likely to get political support where non-local tax payers pay a large proportion of the tax. This is easier where the tax authority is small and most traffic is through traffic. In Scotland road charging cannot be used on trunk roads, so limiting the scope for such practices. However, the proposals set out for the Edinburgh Outer Cordon proposals appear to seek to have a high relative proportion of congestion pricing paid by non-local tax payers. For instance, Edinburgh Council residents living outside the Cordon were to be exempt from charges although they would clearly contribute to congestion. Also Edinburgh has significant evening rush hour congestion for vehicles coming into, as well as leaving, the city. The choice in the final proposals to charge, at the outer cordon, only for inbound traffic during the morning rush hour, further reduced the likely impacts of the proposals on lowering congestion, as Edinburgh residents could leave the city in the morning to work elsewhere (contributing to morning congestion) and return during the heavily congested evening rush hour, but not have to pay a charge. Such car drivers would be exempt from charges and have no related incentive to take public transport. In addition, the use of a cordon system, rather than a zone system (where anyone travelling within the zone would pay the toll) meant that those causing congestion solely within Edinburgh would not be influenced by the charges. This suggested that reducing congestion may have been a secondary motive to the political pressure to gain political support for the referendum to introduce congestion pricing and that congestion pricing for Edinburgh had a high revenue raising component.

Even with this scheme, where those most affected by congestion charging - those vehicles originating outside of Edinburgh - were not consulted in the participation exercise (though this resulted in legal challenges by adjacent authorities and major objections being raised at a Public Inquiry) and not part of the vote, the vote was a "no". If the scheme had been devised to benefit Edinburgh residents at the expense of commuters, at least in the first round, the Edinburgh residents have rejected this source of revenue generation. Whether Edinburgh residents suspected that adoption of the scheme would have seen a tightening regime which eventually would have 
targeted and included them as a revenue source or whether Edinburgh residents were aware of previous revenue earning schemes which had been costly to implement and failed to raise revenue such as the current parking schemes, and whether these factors led the vote, we do not know. Research into the Edinburgh "no" vote is called for if there is to be any benefit to the historic Edinburgh road user charging scheme - the post-mortem should be a thorough one.

\section{References}

Button, K. and E. Vefhoef (eds) (1998) 'Introduction', in Button, K. and E. Vefhoef (eds) Road Pricing, Traffic congestion and the Environment, Edward Elgar, Cheltenham, pp. 3-13.

E. Fietelson and I. Solomon (2004) 'The Political Economy of Transport Innovations', in Beuthe, M., Himanen, V. Reggiani, A. and L. Zamparini, (eds) Developments and Innovations in an Evolving World, Springer, Berlin pp 11-26.

Grieco M. and Jones P.M. (1994) A change in the policy climate? Current European perspectives on road pricing. Urban Studies Volume 31, Issue 9, November, pp. $1517-1532$

Giuliano, G. (1992) An assessment of the political acceptability of congestion pricing. Transportation 19, pp. 335-358

Han, T. (1998) 'Congestion pricing and road investment' in Button, K. and E. Vefhoef (eds) Road Pricing, Traffic congestion and the Environment, Edward Elgar, Cheltenham, pp. 39-78

Harrington, W., Krupnick, A. and Alberini, A. (2001) Overcoming public aversion to congestion pricing. Transportation Research Part A, 35, pp. 93-111

Jones, P. M. (1991) Gaining Public Support for Road Pricing through a package Approach, Traffic Engineering + Control 4, pp. 194-196

Jones, P. (1998) 'Urban Road Pricing; Public Acceptability and Barriers to Implementation', in Button, K. and E. Vefhoef (eds) Road Pricing, Traffic congestion and the Environment, Edward Elgar, Cheltenham, pp. 263-284

Layard, R. (1977) The Distributional Effects of Congestion Taxes, Economica 44, pp. 297-304.

McQuaid, R.W., Greig, M. and J. Adams (2001) "Unemployed Job Seeker Attitudes Towards Potential Travel-to-Work Times", Growth and Change, 32, 356-69 
Rajé, F., Grieco, M, and McQuaid, R.W. (2004) Edinburgh, Road Pricing and the Boundary Problem. Issues of Equity and Efficiency. Scotecon:online at:

http://www.scotecon.net/publications/Greico\%20McQuaid\%20Congestion\%20Final.d $\underline{\mathrm{oc}}$

Rietveld, P. and E. Verhoef 1998 'Social Feasibility of Politics to Reduce Externalities in Transport' in Button, K. and E. Vefhoef (eds) Road Pricing, Traffic congestion and the Environment, Edward Elgar, Cheltenham, pp. 213-246

Small, K. and J. Gomez - Ibanez (1998) 'Road Pricing for Congestion Management the transition from Theory to Practice', in Button, K. and E. Vefhoef (eds) Road Pricing, Traffic congestion and the Environment, Edward Elgar, Cheltenham, pp. 213-246 